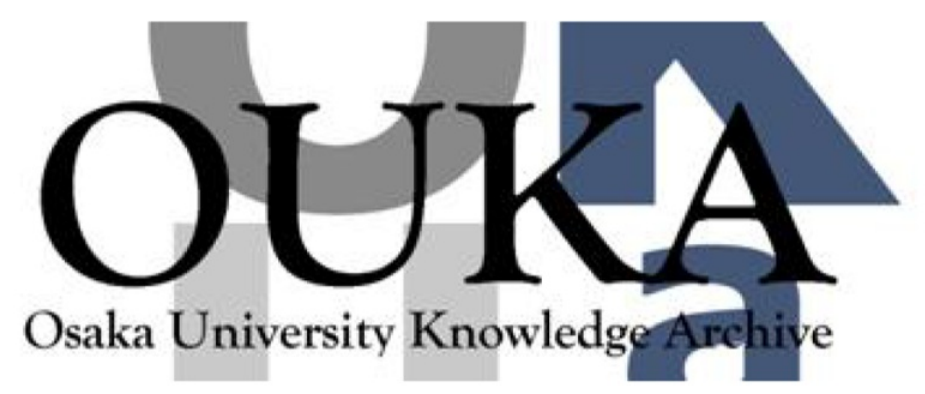

\begin{tabular}{|c|l|}
\hline Title & $\begin{array}{l}\text { Involvement of Estrogen Receptor } \beta \text { in the } \\
\text { Induction of Polyovular Follicles in Mouse } \\
\text { Ovaries Exposed Neonatally to } \\
\text { Diethylstilbestrol }\end{array}$ \\
\hline Author(s) & $\begin{array}{l}\text { Kirigaya, Akio; Kim, Hannah; Hayashi, Shinji et } \\
\text { al. }\end{array}$ \\
\hline Citation & Zoological Science. 26(10) p. 704-p. 712 \\
\hline Issue Date & 2009 \\
\hline oaire:version & VoR \\
\hline URL & https://hdl. handle. net/11094/3068 \\
\hline rights & \\
\hline Note & \\
\hline
\end{tabular}

Osaka University Knowledge Archive : OUKA

https://ir. Library. osaka-u. ac. jp/

Osaka University 


\section{Involvement of Estrogen Receptor $\beta$ in the Induction of Polyovular Follicles in Mouse Ovaries Exposed Neonatally to Diethylstilbestrol}

Author(s) :Akiko Kirigaya, Hannah Kim, Shinji Hayashi, Pierre Chambon, Hajime Watanabe, Taisen lguchi and Tomomi Sato

Source: Zoological Science, 26(10):704-712. 2009.

Published By: Zoological Society of Japan

DOI:

URL: http://www.bioone.org/doi/full/10.2108/zsj.26.704

BioOne (www.bioone.org) is a nonprofit, online aggregation of core research in the biological, ecological, and environmental sciences. BioOne provides a sustainable online platform for over 170 journals and books published by nonprofit societies, associations, museums, institutions, and presses.

Your use of this PDF, the BioOne Web site, and all posted and associated content indicates your acceptance of BioOne's Terms of Use, available at www.bioone.org/page/terms_of_use.

Usage of BioOne content is strictly limited to personal, educational, and non-commercial use. Commercial inquiries or rights and permissions requests should be directed to the individual publisher as copyright holder. 


\title{
Involvement of Estrogen Receptor $\beta$ in the Induction of Polyovular Follicles in Mouse Ovaries Exposed Neonatally to Diethylstilbestrol
}

\author{
Akiko Kirigaya ${ }^{1}$, Hannah Kim², Shinji Hayashi ${ }^{1,2}$, Pierre Chambon ${ }^{3}$, \\ Hajime Watanabe ${ }^{4}$, Taisen Iguchi ${ }^{4}$ and Tomomi Sato ${ }^{1,2 *}$ \\ ${ }^{1}$ Graduate School of Integrated Science and ${ }^{2}$ International Graduate School of Arts and \\ Sciences, Yokohama City University, Yokohama 236-0027, Japan \\ 3 Institut de Génétique et de Biologie Moléculaire et Cellulaire, CNRS/INSERM/ULP, \\ Collége de France, BP163, 67404, Illkirch Cedex, France \\ ${ }^{4}$ The Graduate University for Advanced Studies and Okazaki Institute \\ for Integrative Bioscience, National Institute for Basic Biology, \\ National Institutes of Natural Sciences, Okazaki 444-8787, Japan
}

\begin{abstract}
Natural and synthetic estrogens, including diethylstilbestrol (DES), given during the critical period of newborn life induce abnormalities in ovaries of mice. Induction of polyovular follicles (PFs) containing two or more oocytes in a follicle is one example. In this study, the involvement of estrogen receptor subtypes $E R \alpha$ and $E R \beta$ in induction of PFs by neonatal treatment with DES was analyzed by using ER $\alpha$ knockout ( $\alpha E R K O)$ and ER $\beta$ knockout ( $\beta E R K O)$ mice. Ovaries of mice injected with $3 \mu \mathrm{g}$ DES for 5 days from the day of birth were examined histologically from 10 to 60 days of age, and the expression of genes involved in folliculogenesis was analyzed by real-time quantitative PCR. The PF incidence (percent of PFs per 100 follicles greater than $50 \mu \mathrm{m}$ in diameter) in the ovary of $\alpha$ ERKO mice treated with DES was not different from that in the DES-treated wild-type mice. However, neonatal DES treatment did not increase the PF incidence in $\beta E R K O$ mice, suggesting that PFs were induced by DES through ER $\beta$ but not ER $\alpha$. The expression of bone morphogenetic protein 15, growth differentiation factor 9 , inhibin- $\alpha$, Müllerian inhibiting substance, and other genes in the ovaries of DES-treated $\beta E R K O$ mice was not different from that in the ovaries of DES-treated wild-type mice. These results indicate that ER $\beta$ but not ER $\alpha$ is essential for DES to induce PFs in mice.
\end{abstract}

Key words: ovary, estrogen receptor, ovarian follicle, estrogen, mouse

\section{INTRODUCTION}

Newborn female mice have been used as a rodent model to understand the mechanisms of estrogen action responsible for the human diethylstilbestrol (DES) syndrome in which pregnant women during the period from the 1940s to 1970 s were prescribed DES to prevent miscarriage. Daughters born from these DES-exposed mothers developed vaginal cancer and other reproductive abnormalities (Herbst and Bern, 1981). DES use in women was stopped in 1971. Neonatal DES treatment induces various abnormalities in female mouse reproductive organs, including persistent cornification of the vaginal epithelium (Takasugi, 1963, 1976) and tumorigenesis in the mammary gland (Lopez et al., 1988). Neonatal treatment of mice with DES induces several histological abnormalities in the ovary, including polyovular follicles (PFs) having two or more oocytes in a

\footnotetext{
* Corresponding author. Phone: +81-45-787-2394; Fax : +81-45-787-2413; E-mail: tomomi@yokohama-cu.ac.jp
}

follicle, ovarian cysts, hemorrhagic cysts, hypertrophy of the interstitial tissue, and the absence of corpora lutea. The lack of corpora lutea in the ovaries of neonatally DES-treated mice was caused by lack of a surge of luteinizing hormone (Hayashi and Aihara, 1989; Hayashi et al., 1991; Döhler and Jarzab, 1992).

Estrogen acts through binding to two cognate nuclear receptors, estrogen receptor (ER) $\alpha$ and ER $\beta$, in female reproductive organs. DES binds to both $E R \alpha$ and $E R \beta$ with high affinity compared to $17 \beta$-estradiol $\left(E_{2}\right)$ (Kuiper et al., 1997). The uterus, mammary gland, placenta, liver, central nervous system, cardiovascular system, and bone have high $E R \alpha$ content. ER $\beta$ is detected in the prostate, testis, ovary, pineal gland, thyroid gland, and skin, and is especially highly expressed in the prostatic epithelium, urogenital tract, ovarian follicles, lung, and muscle (Weihua et al., 2003). In mouse ovaries, ER $\alpha$ mRNA and protein are localized in interstitial and thecal cells, and ER $\beta$ expression is detected in the nuclei of granulosa cells (Jefferson et al., 2002; Hishikawa et al., 2003). In studies with ER $\alpha$ knockout $(\alpha E R K O)$ and $E R \beta$ knockout ( $\beta E R K O)$ mice, and the use of ER selective ligands, DES was shown to act through ER $\alpha$ 
but not ER $\beta$ in the induction of squamous epithelial metaplasia in the uterus, proliferative lesions of the oviduct, persistent cornification of the vaginal epithelium, and hypertrophy of the ovarian interstitial tissue (Couse and Korach, 2004; Nakamura et al., 2008).

PFs are found in the ovary of intact mice, rats, hamsters, dogs, and other species of mammals, including humans (Iguchi, 1992; Iguchi and Sato, 2000). The PF incidence is different among strains in intact mice (Kent, 1960), and it is increased markedly by neonatal DES treatment (Forsberg, 1985; Iguchi, 1985; Iguchi et al., 1987). In C57BL/Tw mice, PFs are induced with high incidence by neonatal treatment with estrogens, progestins, and aromatizable androgen, testosterone $(\mathrm{T})$, but not by the non-aromatizable androgens $5 \alpha$-dihydrotestosterone ( $5 \alpha-\mathrm{DHT})$ or $5 \beta$-DHT (Iguchi et al., 1986). In addition, simultaneous administration of aromatase inhibitor (4-hydroxy-4-androstene-3, 17-dion) and T does not induce PFs (Iguchi et al., 1988). The evidence suggests that $\mathrm{T}$ enhances PF induction as a result of its conversion to estrogen (Ryan et al., 1972). DES acts directly on the neonatal ovary to induce PFs both in vivo and in vitro (Iguchi et al., 1990); however, it has been unclear which ER subtype is involved in the PF induction by neonatal DES treatment.

Even without DES treatment, PFs are found in the ovaries of double mutant bone morphogenetic protein 15 (Bmp-15)-/- and growth differentiation factor 9 (Gdf-9)+/mice (Yan et al., 2001). Mice overexpressing inhibin- $\alpha$ gene also show a high incidence of PFs (McMulle et al., 2001). Thus, the induction of PFs by DES may be accompanied by changes in BMP-15 and/or inhibin- $\alpha$ expression. In addition, studies of Müllerian inhibiting substance (MIS) and steroidogenic factor-1 (SF-1) deficient mice suggest that both are critical factors in regulating early ovarian differentiation (Durlinger et al., 1999).

In the present study, DES-treated $\alpha$ ERKO and $\beta E R K O$ mice were used to examine whether DES acts through ER $\alpha$ and/or ER $\beta$ in neonatal mouse ovaries to induce PFs and histological abnormalities. Using real-time quantitative PCR, changes in the expression of several genes reported to be involved in folliculogenesis and in PF occurrence were compared between DES-treated and oil-treated mouse ovaries.

\section{MATERIALS AND METHODS}

\section{Animals}

As the developmental stage of the reproductive tract of mouse neonates corresponds to that of the 3- to 4-month-old human fetus, the neonatal mouse has been used as an animal model of human DES syndrome, in which DES was prescribed during 3-5 months of pregnancy to prevent abortion (Bern and Talamantes, 1981). Therefore, we used neonatal mice for this study.

Female C57BL/6J Jcl mice (CLEA Japan, Tokyo); $\alpha$ ERKO (ER $\alpha-/-)$, wild-type $(E R \alpha+/+)$, and heterozygous (ER $\alpha+/-)$ females; and $\beta$ ERKO (ER $\beta-l-)$, wild-type $(E R \beta+/+)$, and heterozygous $(E R \beta+/-)$ females were given daily subcutaneous (s.c.) injections of $3 \mu \mathrm{g}$ diethylstilbestrol (DES) (Sigma Chemical, St. Louis, MO, USA) dissolved in sesame oil or in the vehicle alone for 5 days, starting on the day of birth (day 0 ).

$\alpha E R K O$ and $\beta E R K O$ mice were obtained by mating mice of a mixed C57BL6/129sv background that were heterozygous for the ER gene disruption, as described previously (Dupont et al., 2000). Pup genotypes were determined by multiplex PCR.

All animals were fed a commercial diet (MF, Oriental Yeast,
Tokyo) and tap water ad libitum and kept at $24 \pm 1.0^{\circ} \mathrm{C}$ under $12 \mathrm{~h}$ light/12 h darkness (artificial illumination; lights on 0800-2000). Animals were maintained in accordance with the NIH Guide for the Care and Use of Laboratory Animals, and the procedures were approved by our institutional animal care committee.

\section{Histological analysis}

Ovaries of C57BL/6J mice at days 5, 10, 20,30,40,50, and $60(n=5), \alpha$ ERKO and $\beta$ ERKO mice at day $30(n=7-10)$, and the respective wild-type and heterozygous mice $(n=4-10)$ treated neonatally with DES or oil vehicle only were fixed in Bouin's solution overnight at room temperature, embedded in paraffin, and serially sectioned at $8 \mu \mathrm{m}$. Sections were stained with haematoxylin and eosin. Every 13th section of ovaries was observed, and the incidence of PFs (\%) was estimated by counting the number of PFs having more than two oocytes per follicle greater than $50 \mu \mathrm{m}$ in diameter per mouse, as described previously (Iguchi et al., 1986). The number of mice with PFs in C57BL/6J, $\alpha$ ERKO, or $\beta E R K O$ mice treated neonatally with DES or the oil vehicle was expressed as the frequency of PFs.

\section{Immunohistochemistry of ER $\beta$}

Ovaries of C57BL/6J mice at days $0,5,10$, and $20(n=3)$ were fixed in $4 \%$ paraformaldehyde in PBS $(\mathrm{pH} 7.4)$ overnight at $4^{\circ} \mathrm{C}$, embedded in paraffin, and sectioned at $4 \mu \mathrm{m}$. Sections were deparaffinized, rehydrated, and microwaved for $8 \mathrm{~min}$ in $10 \mathrm{mM}$ sodium citrate buffer $(\mathrm{pH}$ 6.0) for antigen retrieval. Sections were incubated with $0.3 \% \mathrm{H}_{2} \mathrm{O}_{2}$ for 10 min to eliminate endogenous peroxidase. After washing with PBS, sections were treated with normal goat serum for $30 \mathrm{~min}$, and then incubated overnight at $4{ }^{\circ} \mathrm{C}$ with rabbit polyclonal antibody against mouse ER $\beta$ (Zymed Laboratories, South San Francisco, CA, USA) at a dilution of 1:250, or with the rabbit IgG fraction (Dako Cytomation, Glostrup, Denmark) as a negative control. After incubation with secondary antibody streptavidin conjugated to horseradish peroxidase, the Elite Standard ABC Kit (Vector Laboratories, Burlingame, CA, USA) and $1 \mathrm{mg} / \mathrm{ml}$ diaminobenzidine (Sigma Chemical) in PBS containing $1 \% \mathrm{H}_{2} \mathrm{O}_{2}$ were used for ER $\beta$ detection.

\section{Real-time quantitative PCR}

Total RNA was isolated from ovaries of neonatally DES-treated or oil-treated C57BL/6J mice at days 5, 10,20,30,40,50, and 60, and neonatally DES-treated or oil-treated wild-type $(E R \beta+/+)$ and $\beta E R K O$ $(E R \beta-l-)$ mice at days 10, 20, and 30, and reverse-transcribed with Super Script II reverse transcriptase (Invitrogen, Carlsbad, CA, USA) using $0.05 \mathrm{mM}$ oligo dT primer (Invitrogen). Real-time quantitative PCR was carried out with an ABI PRISM 7000 Sequence Detection System using SYBR Green Master Mix (Applied Biosystems, Foster City, CA, USA). The relative mRNA expression of BMP-15, GDF-9, inhibin- $\alpha$, MIS, kit (KIT), kit ligand (KL), insulin-like growth factor I (IGF-I), SF-1, steroidogenic acute regulatory protein (StAR), cholesterol side-chain cleavage cytochrome P450 (P450SCC), ER $\alpha$, and ER $\beta$ (Table 1) was determined by the standard curve method. Cyclophilin was chosen as an internal standard to control for variability in amplification due to differences in starting mRNA concentration. One to ten mice were used for each time point. Independent experiments were carried out at least three times for each gene.

\section{Statistical analysis}

Data are expressed as the mean \pm standard error. For multiple comparisons, treatment groups were compared using analysis of variance (ANOVA) followed by Dunnett's post-hoc test. Two-tailed Student's $t$-tests were used for single comparisons. Fisher's exact probability test was used to examine the significance of the association between the two kinds of classification. A statistically significant difference was defined as $\mathrm{p}<0.05$. 


\section{RESULTS}

Polyovular follicles (PFs) in the ovary of DES-treated C57BL/6J mice

The histology of ovaries from 5- and 10-day-old mice showing ovarian follicles in a variety of stages was not altered by neonatal DES treatment. Corpora lutea were found in the ovaries of C57BL/6J control mice at day 40 or older, but not in the ovaries of any DES-treated mice (data not shown). This result corresponds with a previous report (Iguchi, 1992).

PFs greater than $50 \mu \mathrm{m}$ in diameter were found in the ovaries of all DES-treated C57BL mice at day 10 or older. In control mice, $20-100 \%$ of mice had PFs in the ovary from days 10 to 60; therefore, DES treatment did not significantly increase the PF frequency (percent of mice with PFs), except in 60-day-old mice (Table 2). The number of follicles greater than $50 \mu \mathrm{m}$ in diameter was significantly higher in the ovaries of 20- to 60-day-old mice than in those of 10-dayold mice in both the oil- and DES-treated groups. In 30- and 50-day-old DES-treated mice, the total number of follicles was larger compared to the age-matched oil controls (Fig. 1A). The PF incidence (percent of PFs per 100 follicles greater than $50 \mu \mathrm{m}$ in diameter) was significantly higher in DES-treated mice from days 20 to 60 than in the age-

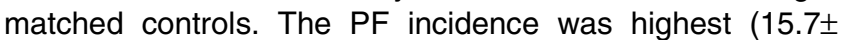
$2.02 \%$ ) in neonatally DES-treated mice at day 20 and decreased gradually with age (Fig. 1B). The total number of PFs per ovary in DES-treated mice increased to day 30 and then decreased with age. PFs with two or three oocytes were significantly higher at days 20 to 40 (Fig. 1C).

\section{Expression of genes involved in folliculogenesis in C57BL/6J mice}

To analyze the mRNA expression of folliculogenesisrelated genes, including BMP-15, GDF-9, inhibin- $\alpha$, MIS, Kit, $\mathrm{KL}$, and IGF-I, real-time quantitative PCR was performed. In

Table 2. Number and frequency of mice with PFs among C57BL/ $6 \mathrm{~J}$ mice treated neonatally with the oil vehicle or with $3 \mu \mathrm{g}$ DES.

\begin{tabular}{|c|c|c|c|c|c|c|c|}
\hline \multirow[b]{2}{*}{ Treatments } & & \multicolumn{6}{|c|}{ Days of age } \\
\hline & & 10 & 20 & 30 & 40 & 50 & 60 \\
\hline Oil & $\begin{array}{c}\text { No. of mice } \\
\text { with PFs / No. } \\
\text { of mice examined }\end{array}$ & $2 / 5$ & $5 / 5$ & $2 / 5$ & $4 / 6$ & $2 / 5$ & $1 / 5$ \\
\hline & PFs frequency (\%) & 40 & 100 & 40 & 67 & 40 & 20 \\
\hline DES & $\begin{array}{c}\text { No. of mice } \\
\text { with PFs / No. } \\
\text { of mice examined }\end{array}$ & $5 / 5$ & $5 / 5$ & $5 / 5$ & $5 / 5$ & $5 / 5$ & $5 / 5^{\star}$ \\
\hline & PFs frequency (\%) & 100 & 100 & 100 & 100 & 100 & 100 \\
\hline
\end{tabular}

A

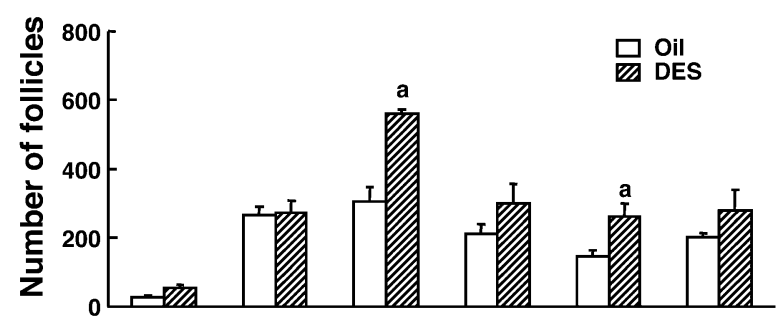

B

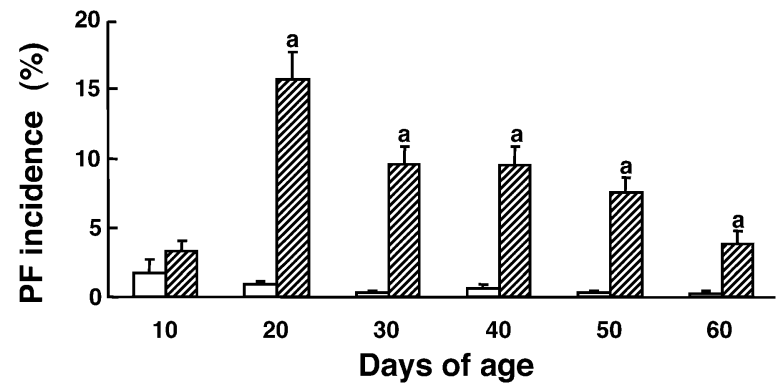

C

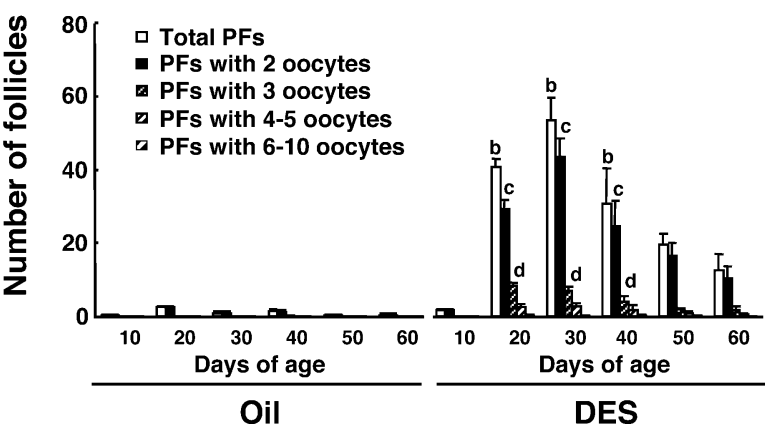

Fig. 1. (A) Number of follicles and (B) incidence of polyovular follicles (PFs) in ovaries of C57BL/6J mice treated neonatally with oil or with $3 \mu \mathrm{g}$ DES. (C) Number of total PFs and PFs with 2, 3, 4 to 5, or 6 to 10 oocytes per follicle in ovaries of C57BL/6J mice treated neonatally with oil or with $3 \mu \mathrm{g}$ DES. Data are expressed as the mean \pm standard error. a, significantly different $(p<0.05)$ from agematched oil-treated controls (Student's $t$-test); b, c, d, significantly different $(p<0.05)$ from 10-day-old mice treated neonatally with DES (Dunnett's test). Five mice were used for each time point. 
the ovaries of control mice, the expression of BMP-15, GDF9, MIS, and IGF-I showed a peak at day 10. The expression of Kit and KL decreased with age. Inhibin- $\alpha$ expression gradually increased to day 20 and remained at a plateau until day 50. Neonatal DES treatment did not affect the expression of any of the genes studied from days 5 to 60, except for inhibin- $\alpha$, which showed a significantly higher level in DEStreated ovaries than in controls at day 60 (Fig. 2).

\section{Expression of ER $\alpha$ and ER $\beta$ mRNA and ER $\beta$ protein in ovaries of C57BL/6J mice treated neonatally with DES}

In oil controls, ER $\alpha$ expression showed no alteration from day 0 to day 60 . In contrast, ER $\beta$ mRNA was significantly higher at days 20 and 30 compared to day 0 (Fig. 3). Neither the ER $\alpha$ nor the ER $\beta$ mRNA level was altered by neonatal DES treatment (Fig. 3), even though control mice from days 40 to 60 had corpora lutea.

No distinct difference in ER $\beta$ immunoreactivity was discernible between PFs and normal follicles (Fig. 4A). ER $\beta$ was detected distinctly in the nuclei of granulosa cells. No

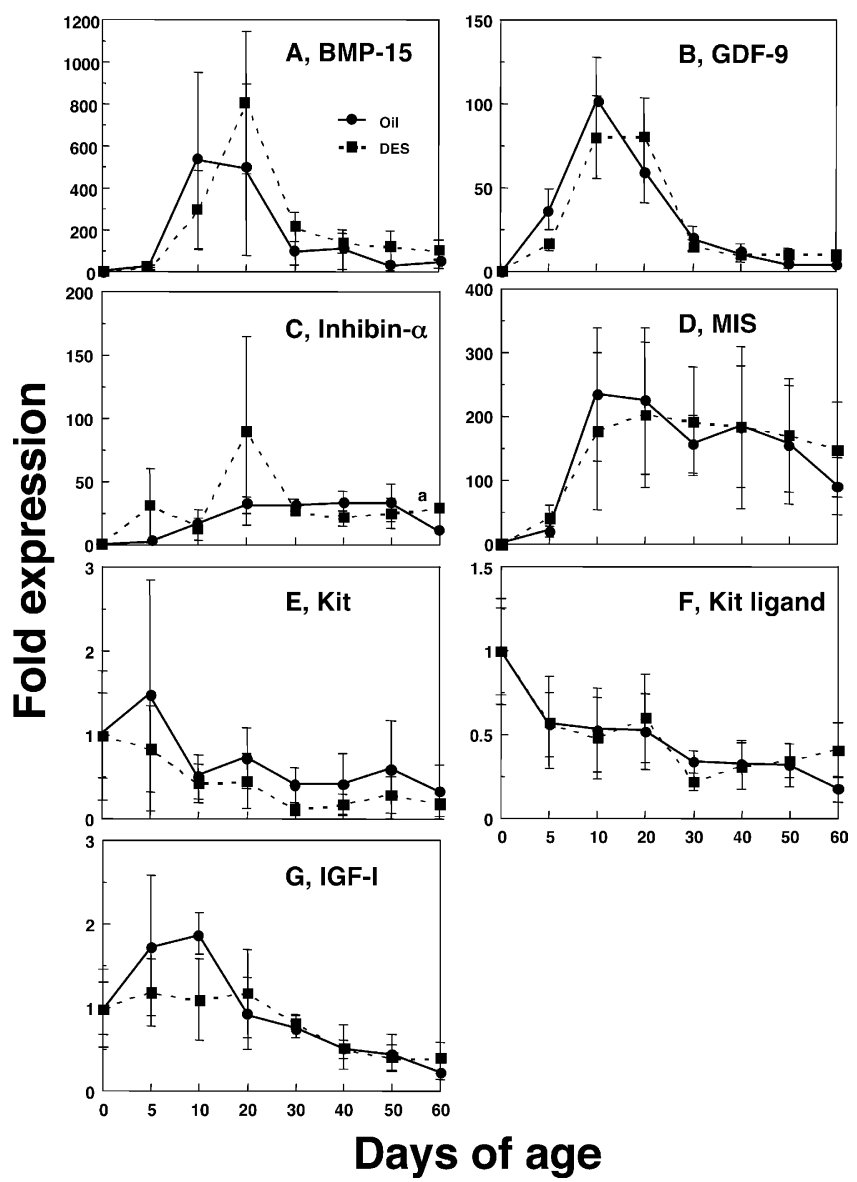

Fig. 2. Ontogenic expression of genes reported to be involved in folliculogenesis in neonatally oil- or DES-treated C57BL/6J mice, determined by real-time quantitative PCR. All measurements are normalized to the cyclophilin mRNA level and are shown relative to the mRNA expresson level at day 0 . Data are expressed as the mean \pm standard error. a, significantly different $(p<0.05)$ from agematched oil-treated mice (Student's $t$-test). One to ten mice were used for each time point, and independent experiments were carried out at least three times for each gene.
ER $\beta$ staining was observed in the ovaries of mice at day 0 ; however, granulosa cells began to express ER $\beta$ protein from day 5 and showed positive immunohistochemical staining through day 20 (Fig. 4C, E). ER $\beta$ showed no difference in immunoreactivity between the ovaries from DES-treated mice and those from oil controls (Fig. 4C-F).

\section{Histological analysis of ovaries from $\alpha$ ERKO and $\beta E R K O$ mice at day $\mathbf{3 0}$}

Ovaries of oil-injected wild-type mice $(E R \alpha+/+$ and $E R \beta+/+$ ) at day 30 showed various stages of follicles (Fig. $5 A)$. PFs were encountered in the age-matched wild-type mice treated neonatally with DES (Fig. 5B). Hemorrhagic cysts and follicular cysts were found in the ovaries of both oil-treated and DES-treated $\alpha$ ERKO (ER $\alpha-/-)$ mice (Fig. 5C, $D)$. In DES-treated $\alpha E R K O$ mice, PFs were induced as in the DES-treated wild-type mice (Fig. 5D). Unlike $\alpha E R K O$ mice, the ovaries of $\beta E R K O(E R \beta-/-)$ mice treated with oil or DES showed normal follicles at all stages of development, without hemorrhagic cysts or follicular cysts (Fig. 5E, F). Neonatal DES treatment in $\beta E R K O$ mice (Fig. 6B) did not increase the PF incidence. The ovaries of heterozygotes (ER $\alpha+/-$ and $E R \beta+/-$ mice) were not histologically different from those of wild-type mice, and the effects of DES on the ovary of these heterozygous mice were similar to those in wild-type mice having PFs (data not shown).

\section{PFs in DES-treated $\alpha E R K O$ and $\beta E R K O$ mice}

The number of follicles in ovaries of $\alpha$ ERKO (ER $\alpha-/-)$

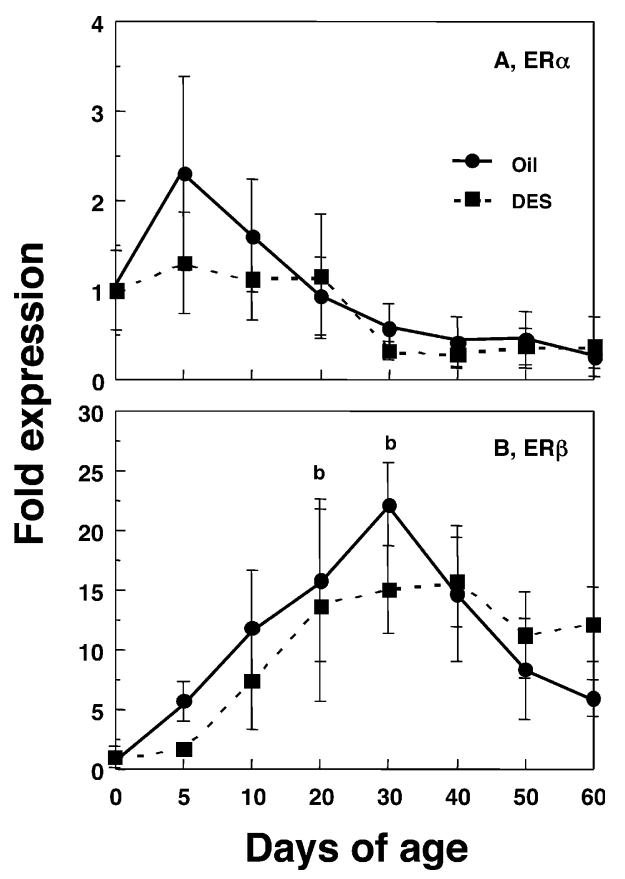

Fig. 3. Ontogenic expression of $E R \alpha$ and $E R \beta$ mRNAs in the ovaries of oil- or DES-treated C57BL/6J mice, determined by real-time quantitative PCR. Cyclophilin was used as an internal standard to control for variability in amplification due to differences in starting mRNA concentration. Data are expressed as the mean \pm standard error. One to ten mice were used for each time point, and independent experiments were carried out at least three times for each gene. $b$, significantly different $(p<0.05)$ from 0 -day-old control mice. 


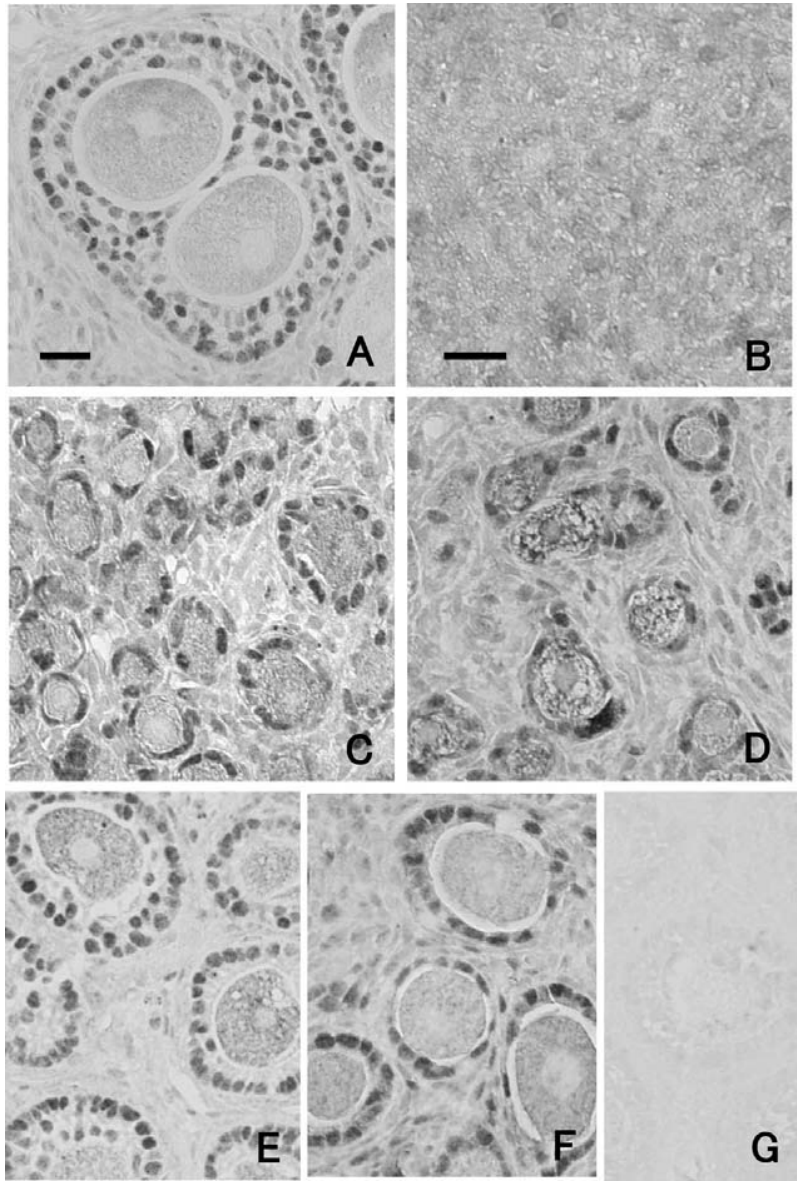

Fig. 4. Immunohistochemical staining of $E R \beta$ protein in ovaries of C57BL/6J mice. (A) ER $\beta$ positive staining in a PF at day 20. (B-F) ER $\beta$ expression in the ovary of a day 0 mouse (B), day 5 mice treated neonatally with oil (C) or with DES (D), and day 10 mice treated with oil $(\mathbf{E})$ or with DES (F). (G) Ovary of a day-10 mouse incubated with the rabbit IgG fraction as a negative control. The cytoplasm of oocytes was occasionally stained, but this was also observed in the negative control. Three mice were used for each time point. Scale bars, $25 \mu \mathrm{m}$.

and $\beta E R K O$ (ER $\beta-/-)$ mice was not different from respective wild-type mice (ER $\alpha+/+$, ER $\beta+/+)$ or heterozygous (ER $\alpha+/-$, $E R \beta+/-)$ mice. In ER $\beta$ wild-type mice $(E R \beta+/+)$, DES treatment significantly increased the number of follicles (Fig. 6A).

Neonatal DES treatment significantly increased the PF incidence (percent of PFs per 100 follicles greater than 50 $\mu \mathrm{m}$ in diameter) in ovaries of ER $\alpha$ wild-type, heterozygous, and $\alpha E R K O$ mice (Fig. 6B). The PF incidence was not different among DES-treated $\alpha E R K O$ mice, ER $\alpha$ heterozygous mice, and wild-type mice (9.2-10.5\%). DES-treated ER $\beta$ wild-type and heterozygous mice showed a high incidence of PFs; however, DES treatment did not increase the PF incidence in $\beta E R K O$ mice compared to that in oil-treated $\beta E R K O$ mice (Fig. $6 \mathrm{~B}$ ). In the oil controls, $20-60 \%$ of mice had PFs in the ovary at day 30 , regardless of genotype, and DES treatment did not alter the PF frequency (percent of mice with PFs), except in ER $\beta$ heterozygous mice (Table 3).

The total number of PFs and the number of PFs with 2, 3,4 to 5 , or 6 to 10 oocytes were not different among gen-
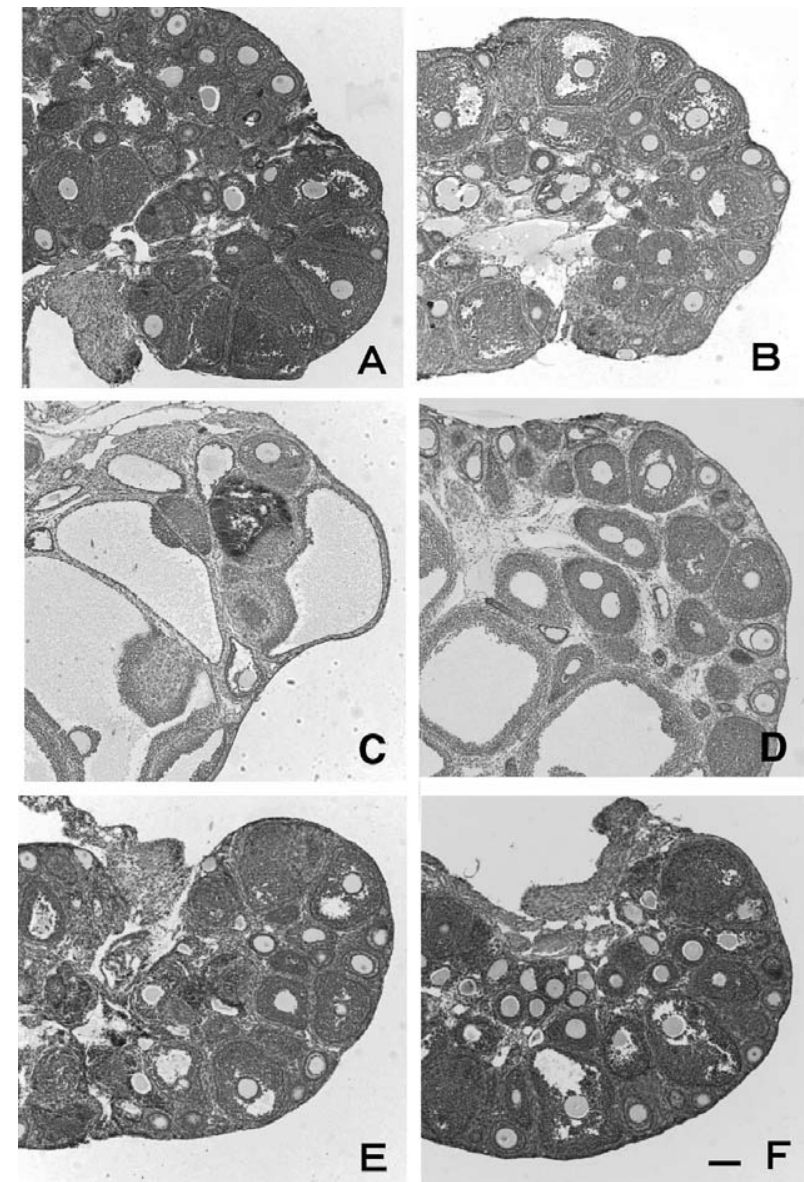

Fig. 5. Ovarian histology of day-30 wild-type $E R \alpha+/+$ (A) and $\mathrm{ER} \beta+/+$ (B) mice, $\alpha$ ERKO (ER $\alpha-/-)$ mice (C, D), and $\beta E R K O$ (ER $\beta-$ $/-)(E, F)$ mice treated neonatally with oil $(\mathbf{A}, \mathbf{C}, \mathbf{E})$ or with $3 \mu \mathrm{g}$ DES (B, D, F). Four to ten mice were used. Scale bar, $100 \mu \mathrm{m}$.

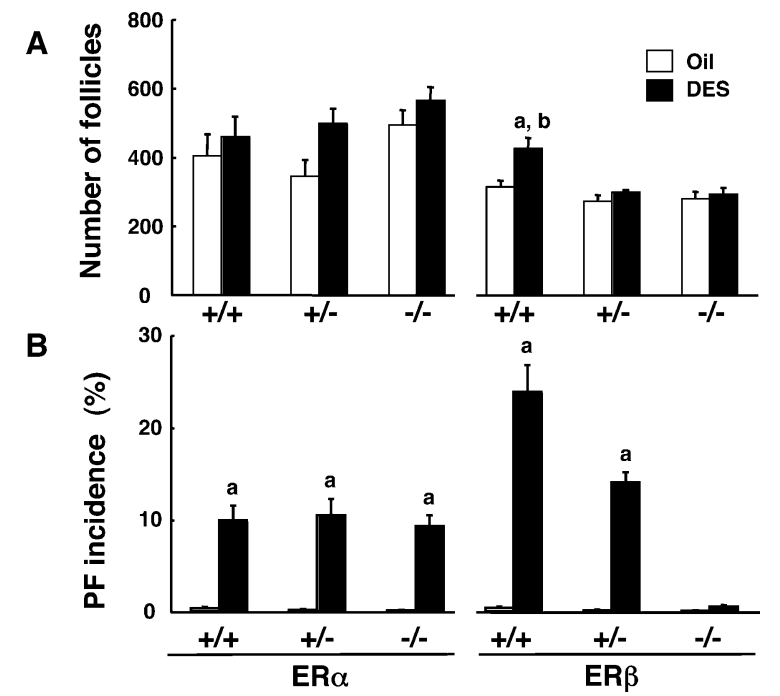

Fig. 6. (A) Number of follicles and (B) incidence of PFs in ovaries of 30-day-old wild-type $(E R \alpha+/+$, ER $\beta+/+)$, heterozygous (ER $\alpha+/-$, $\mathrm{ER} \beta+/-)$, $\alpha$ ERKO $(\mathrm{ER} \alpha-l-)$, and $\beta$ ERKO $(\mathrm{ER} \beta-/-)$ mice treated neonatally with oil or with $3 \mu \mathrm{g}$ DES. Data are expressed as the mean \pm standard error. a, significantly different $(p<0.05)$ from genotype-matched oil-treated mice; $b$, significantly different $(p<0.05)$ from DES-treated heterozygotes and $\beta E R K O$ mice (Student's $t$-test). 
Table 3. Number and frequency of mice with PFs among different phenotypes of 30-day-old mice treated neonatally with DES or with the oil vehicle alone.

\begin{tabular}{cccc}
\hline Treatments & Genotypes & $\begin{array}{c}\text { No. of mice } \\
\text { with PFs }\end{array}$ & $\begin{array}{c}\text { Frequency of mice } \\
\text { with PFs }(\%)\end{array}$ \\
\hline Oil & ER $\alpha+/+$ & $3 / 5$ & 60 \\
& ER $\alpha+/-$ & $2 / 5$ & 40 \\
& ER $\alpha-/-$ & $3 / 7$ & 43 \\
& ER $\beta+/+$ & $3 / 5$ & 60 \\
& ER $\beta+/-$ & $1 / 4$ & 25 \\
DES & ER $\beta-/-$ & $2 / 10$ & 20 \\
& ER $\alpha+/+$ & $5 / 5$ & 100 \\
& ER $\alpha+/-$ & $5 / 5$ & 100 \\
& ER $\alpha-/-$ & $7 / 7$ & 100 \\
& ER $\beta+/+$ & $5 / 5$ & 100 \\
& ER $\beta+/-$ & $10 / 10^{*}$ & 100 \\
& ER $\beta-/-$ & $5 / 8$ & 63 \\
\hline
\end{tabular}

*, significantly different $(p<0.05)$ from oil-treated ER $\beta+/-$ mice (Fisher's exact probability test).

A

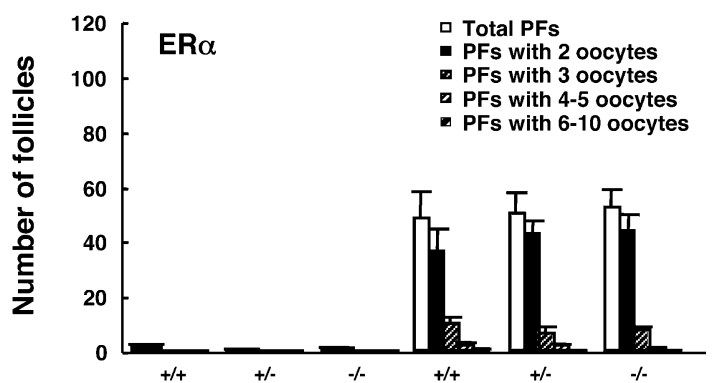

B

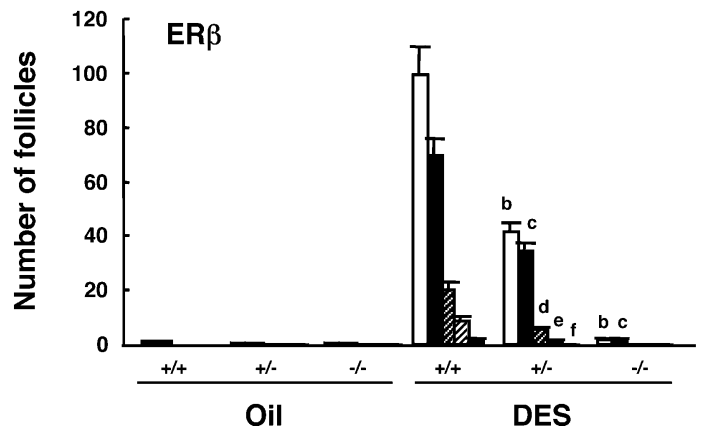

Fig. 7. (A) Number of total PFs and (B) PFs with 2, 3, 4 to 5, or 6 to 10 oocytes per follicle in ovaries of 30-day-old wild-type (ER $\alpha+/+$, $E R \beta+/+)$, heterozygous $(E R \alpha+/-, E R \beta+/-), \alpha$ ERKO (ER $\alpha-/-)$, and $\beta E R K O(E R \beta-/-)$ mice treated neonatally with oil or with $3 \mu \mathrm{g}$ DES. $b, c, d, e, f$, significantly different $(p<0.05)$ from total PFs, with 2 oocytes, 3 oocytes, 4-5 oocytes, or 6-10 oocytes in wild-type $(E R \beta+/+)$ mice treated with DES, respectively. Four to ten mice were used for each time point.

otypes in the DES-treated $\alpha E R K O$ mouse group (Fig. 7A). DES-treated ER $\beta$ wild-type $(E R \beta+/+)$ mice showed PFs with 10 oocytes. DES-treated $\beta E R K O$ mice had PFs with two oocytes, but the number of PFs was significantly lower than in wild-type and heterozygous (ER $\beta+/-)$ mice treated neonatally with DES (Fig. 7B).

\section{Expression of genes involved in folliculogenesis and steroidogenesis in $\beta E R K O$ mice}

The expression of BMP-15 showed a peak at day 10 in

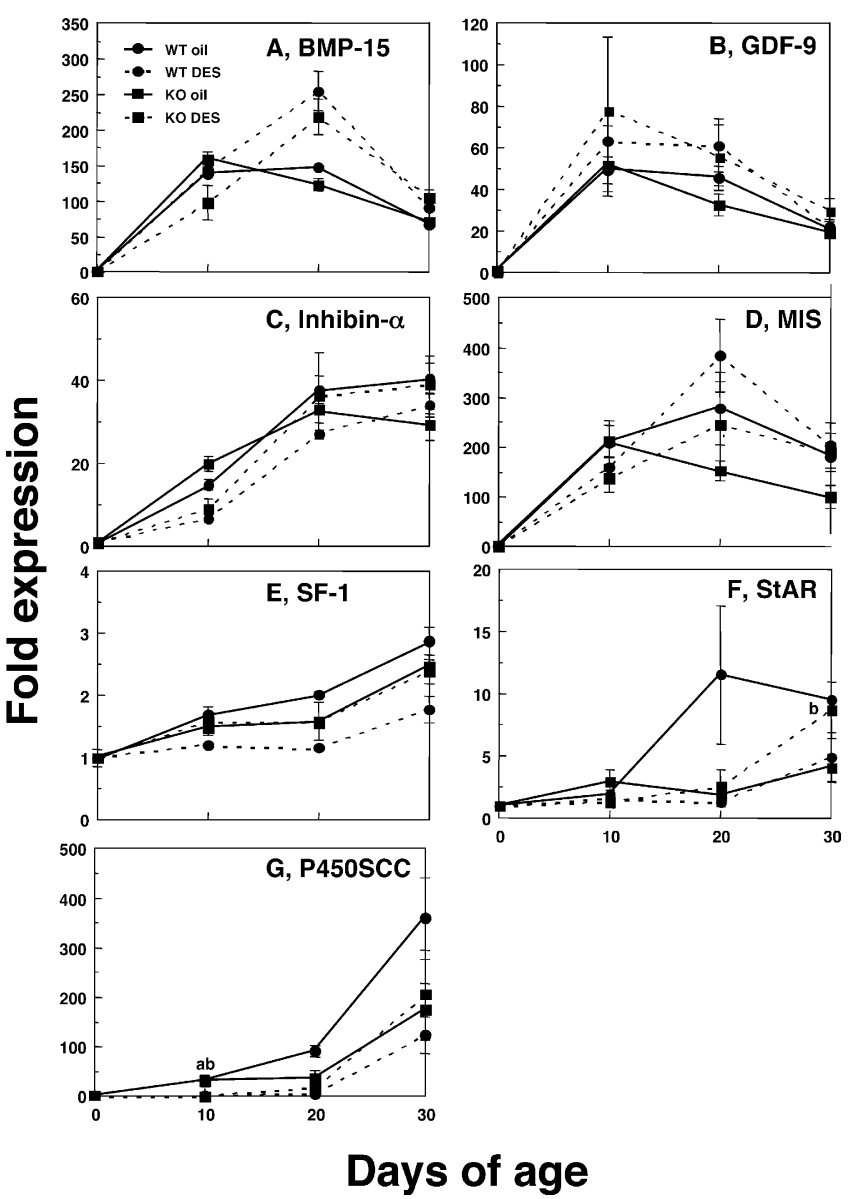

Fig. 8. Ontogenic expression of genes involved in folliculogenesis or steroidogenesis in oil- or DES-treated wild-type $(E R \beta+/+)$ or $\beta E R K O(E R \beta-/-)$ mice, determined by real-time quantitative PCR. All measurements are normalized to the cyclophilin mRNA level and are shown relative to the mRNA expression level of 0-day-old mice. Data are expressed as the mean \pm standard error. a, significantly different $(p<0.05)$ from age-matched oil-treated wild-type mice (Student's $t$-test); $b$, significantly different $(p<0.05)$ from agematched oil-treated $\beta E R K O$ mice (Student's $t$-test). One to ten mice were used for each time point, and independent experiments were carried out at least three times for each gene.

oil-injected wild-type mice and $\beta E R K O$ mice. Neonatal DES treatment shifted the peak to day 20 in both wild-type and $\beta E R K O$ mice (Fig. 8A). The expression of GDF-9 showed a peak at day 10 in wild-type and $\beta E R K O$ mice, irrespective of DES treatment. Expression of inhibin- $\alpha$, SF-1, and P450SCC increased with age. Neonatal DES treatment did not affect the expression of GDF-9, inhibin- $\alpha$, MIS, or SF-1 in either wild-type or $\beta E R K O$ mice (Fig. 8B-E). The expression of StAR peaked at day 20 in wild-type mice but remained low in $\beta E R K O$ mice; however, neonatal DES treatment significantly increased the expression in $\beta E R K O$ mice at day 30 (Fig. 8F). In both wild-type and $\beta E R K O$ mice, neonatal DES treatment significantly reduced the expression of P450SCC at day 10 (Fig. 8G).

\section{DISCUSSION}

In mouse ovaries, ER $\alpha$ protein and mRNA are detected 
in the nuclei of interstitial and thecal cells, and ER $\beta$ protein and mRNA are found in the nuclei of granulosa cells, but not in cells in atretic follicles or corpora lutea (Hishikawa et al., 2003). The localization of ERs suggests that ER $\beta$ may play a principal role in follicular development, while $\mathrm{ER} \alpha$ may be involved in $\mathrm{LH}$ action and androgen synthesis. Indeed, $\alpha$ ERKO mouse ovaries exhibit not only hemorrhagic and cystic follicles but also growing follicles in the pre-antral to small antral stages. The phenotypes of $\beta E R K O$ mouse ovaries suggest a reduction in completed folliculogenesis (Couse and Korach, 1999). Thus, ER $\alpha$ and ER $\beta$ are quite distinct in function in the rodent ovary.

In the present study, neonatal DES treatment increased neither the PF frequency nor the PF incidence in $\beta E R K O$ mice, whereas DES treatment significantly increased the PF incidence in $\alpha E R K O$ mice. PFs were also found in C57BL/ $6 \mathrm{~J}$ control mice (20-100\%), but the PF incidence was low. All DES-treated C57BL/6J mice showed PFs, and the PF incidence increased significantly at day 20 and older. Nakamura et al. (2008) showed that neonatal treatment with a specific ligand of ER $\alpha$ (propyl pyrazole triol) induces PFs in C57BL mice, but they also showed in a transactivation assay that the ligand could activate ER $\beta$ activity at a higher concentration. Therefore, the possibility cannot be ruled out that the ER $\alpha$-specific ligand acts through ER $\beta$ in the mouse ovary. Jefferson et al. (2002) reported the induction of PFs by neonatal treatment with $100 \mu \mathrm{g} /$ pup of genistein, a potent phytoestrogen, at day 19, and they found PFs in only one of $12 \beta E R K O$ mice. While the binding affinity of genistein to $E R \beta$ is 20 times higher than that to ER $\alpha$, DES binds to ER $\alpha$ and ER $\beta$ with equal relative affinity (Kuiper et al., 1998). Although the affinities of ER $\alpha$ and ER $\beta$ to DES were equal, DES treatment did not significantly increase the PF incidence in $\beta E R K O$ mice, but did significantly increased the PF incidence in $\alpha E R K O$ mice, suggesting that neonatal DES treatment induces PFs through ER $\beta$ but not ER $\alpha$. In the present study, ER $\beta$ protein was not detected at day 0 , but it was detected by day 5 . In addition, neonatal treatment with an ER $\beta$-specific agonist, 2,3-bis(4-hydrocyphenyl)-propionitrile (25 $\mu \mathrm{g} /$ pup for 5 days from the day of birth, $n=5$ ), also induced PFs in all wild-type mice at day 30 . The PF incidence in oil controls and the ER $\beta$ agonist-treated mice was 0.6 and $4.3 \%$, respectively (unpublished data).

The estrogen-related receptors (ERRs), an orphan family of nuclear receptors identified initially by similarity to $E R \alpha$ (Giguére et al., 1988), are not activated by natural estrogens, but DES can bind and inhibit the transcriptional activity of ERR $\alpha, \beta$, and $\gamma$ (Tremblay et al., 2001). While $E R R \alpha$ has a potential role in the regulation of metabolic homeostasis, loss of ERR $\beta$ or ERR $\gamma$ results in mid-gestational or neonatal death due to placental defects or failure of the perinatal transition in metabolic state (Luo et al., 1997; 2003; Alaynick et al., 2007; Dufour et al., 2007). However, the expression of ERRs in the ovaries of neonatal wild-type and $\beta E R K O$ mice has not been examined; therefore, the role of ERRs in the induction of PFs by DES needs to be clarified in the near future.

An increase and decrease of ER $\beta$ mRNA with age may be correlated with follicle number and follicular development, because ER $\beta$ is high in preantral and small antral follicles, but not in the Graffian follicles or corpora lutea in rats
(Fitzpatrick et al., 1999). In contrast, ER $\alpha$ is found in the interstitial cells of the ovary from the day of birth, and mRNA expression is not altered until 26 days of age in mice (Jefferson et al., 2000). The ontogeny and distribution of $E R \alpha$ and $E R \beta$ in the rat ovary are similar to that in the mouse ovary (Sar and Welsch, 1999). In addition, no ER $\beta$ staining was observed in the ovaries of mice at day 0 ; however, positive immunohistochemical staining of ER $\beta$ was evident in granulosa cells from days 5 through 20, coinciding with the changes in ER $\beta$ mRNA expression.

In adult human females, the incidence of PFs ranges from $24 \%$ to $85 \%$, depending on the study (Gougeon, 1981; Dandekar et al., 1988); both reports agree that the proportion of PFs among total follicles in the human ovary is less than $1 \%$. No report is available concerning PFs in DESexposed humans; however, chronic implants of DES increase PFs in adult squirrel monkeys (Graham and Bradley, 1971). In the human ovary, ER $\beta$ is localized in the granulosa cells of follicles at all stages of development, whereas ER $\alpha$ is absent from granulosa cells but present in thecal cells (Pelletier and El-Alfy, 2000). Thus, it appears that each receptor subtype can exert a different function according to its specific cellular localization in the human ovary.

In the ovary, ER $\beta$ is highly expressed in granulosa cells, as discussed above. Our results show clearly that ER $\beta$ participates in the induction of PFs by neonatal DES exposure. ER $\beta$ expression is observed in the granulosa cells, but not in the oocytes, of rat and human ovaries (Sar and Welsch, 1999; Jakimiuk et al., 2002; Scobie et al., 2002), while ER $\beta$ mRNA is detected in the cumulus-oocyte complexes and denuded oocytes of mice after PMSG and hCG injections (Hiroi et al., 1999). Jefferson et al. (2006) demonstrated that the suppression of oocyte cell death by neonatal genistein treatment results in PFs. Our previous report suggests that a delay in or inhibition of oocyte death and an increase in inhibin- $\alpha$ by DES through ER $\beta$ may be a trigger for PFs formation (Kim et al., in press). Therefore, DES may indirectly affect oocyte cell death and induce PFs.

The PF incidence increases only when neonatal DES treatment starts within 3 days after birth (Iguchi et al., 1986). Exposure to DES from days 15 to 18 of gestation in utero also induces a high incidence of PFs in offspring (Iguchi and Takasugi, 1986). Folliculogenesis proceeds in ovaries of the fetus and neonate. Syncytia, clusters formed by germ cells, are invaded by somatic cells and undergo programmed breakdown before the formation of primordial follicles (Epifano and Dean, 2002). Thus, DES may induce PFs by disrupting the interaction between oocytes and somatic cells or granulosa cells, and/or by disrupting syncytial breakdown in folliculogenesis.

Folliculogenesis is under the control of molecular interactions between germ cells and somatic cells, and is thought to involve several genes, e.g. Fig $\alpha$, Wnt4, Kit, KL, Cx43, MIS, GDF9, and FecX (Epifano and Dean, 2002). Double mutant Gdf9+/- and Bmp15-/- mice show PFs in their ovaries without DES treatment (Yan et al., 2001). The expression of GDF-9 and BMP-15 is localized in oocytes (McGrath et al., 1995; Dube et al., 1998), and that of inhibin- $\alpha$ and MIS in granulosa cells (Meunier et al., 1988; Ikeda et al., 2002). In the present study, neonatal DES exposure did not alter the expression of these genes in C57BL/6J, ER $\beta$ wild-type, 
or $\beta E R K O$ mice; therefore, further studies are needed to clarify the genes related to PF induction by neonatal DES exposure.

Kipp et al. (2007) reported that neonatal DES or estrogen treatment decreased activin $\beta$-subunit mRNA and protein levels, with a reduction in the number of small antral follicles and the induction of PFs on postnatal day 19. Moreover, mice overexpressing inhibin- $\alpha$ show PFs in their ovaries without DES treatment (McMulle et al., 2001). In our study, the expression of inhibin- $\alpha$ subunit mRNA in DES-treated C57BL/6J mice was significantly higher than in oil controls only at day 60 . At day 5 , inhibin- $\alpha$ subunit mRNA showed no significant change. Thus, the up-regulation of inhibin- $\alpha$ at day 60 may not be directly related to PF induction by DES. The balance of inhibin and activin expression in the ovary could be important in the induction of PFs, and this needs to be clarified in the near future.

MIS and SF-1 are detected in rat granulosa cells, and MIS is a target gene of SF-1 (Ikeda et al., 1994, 2002; Hanley et al., 2000). Both MIS and SF-1 are critical factors regulating early ovarian differentiation (Durlinger et al., 1999). Therefore, we studied the effects of DES on expression of these genes; however, we detected no change in the expression of these genes.

In both wild-type and $\beta E R K O$ mice, DES treatment significantly reduced the expression of P450SCC at day 10 . The expression of P450SCC is localized in interstitial cells (Ikeda et al., 2001), and these cells contain ER $\alpha$ protein. Thus, DES possibly suppresses P450SCC mRNA expression via ER $\alpha$. Since hypertrophy of the interstitium is not observed in neonatally DES-treated $\alpha E R K O$ mice (Couse et al., 2001), ER $\alpha$ may mediate the effects of DES on interstitial cells.

In conclusion, neonatal DES treatment induces PFs through ER $\beta$ but not ER $\alpha$, while DES acts on ovarian interstitial cells through $\mathrm{ER} \alpha$. Further studies are essential to clarify the molecular mechanisms involved in the induction of PFs.

\section{ACKNOWLEDGMENTS}

This work was partially supported by a Grant-in-Aid for Scientific Research on Priority Areas (A) (T. S. and T. I.), a Grant-in-Aid for Scientific Research (B) (T. I.), and a Grant-in-Aid for Encouragement of Young Scientists (T. S.) from the Ministry of Education, Culture, Sports, Science and Technology of Japan; a Grant for Support of the Promotion of Research at Yokohama City University (S. H. and T. S.); a Health Sciences Research Grant from the Ministry of Health, Labor and Welfare, Japan (T. I.); and a Grant for the Support of Collaborative Study at NIBB (T. S).

\section{REFERENCES}

Alaynick WA, Kondo RP, Xie W, He W, Dufour CR, et al. (2007) ERRgamma directs and maintains the transition to oxidative metabolism in the postnatal heart. Cell Metab 6: 13-24

Bern HA, Talamantes FJ Jr (1981) Neonatal mouse models and their relation to disease in the human female. In "Developmental Effects of Diethylstilbestrol (DES) in Pregnancy" Ed by AL Herbst, HA Bern, Thieme Stratton, New York, pp 129-147

Couse JF, Korach KS (1999) Estrogen receptor null mice: what have we learned and where will they lead us? Endocr Rev 20: 358-417

Couse JF, Korach KS (2004) Estrogen receptor-alpha mediates the detrimental effects of neonatal diethylstilbestrol (DES) exposure in the murine reproductive tract. Toxicology 205: 55-63

Couse JF, Dixon D, Yates M, Moore AB, Ma L, Maas R, Korach KS (2001) Estrogen receptor-alpha knockout mice exhibit resistance to the developmental effects of neonatal diethylstilbestrol exposure on the female reproductive tract. Dev Biol 15: 224238

Dandekar PV, Martin MC, Glass RH (1988) Polyovular follicles associated with human in vitro fertilization. Fertil Steril 49: 483486

Döhler KD, Jarzab B (1992) The influence of hormones and hormone antagonists on sexual differentiation of the brain. In "ChemicallyInduced Alterations in Sexual and Functional Development: The Wildlife/Human Connection" Ed by T Colborn, C Clement, Princeton Scientific Publishing, Princeton, pp 231-259

Dube JL, Wang P, Elvin J, Lyons KM, Celeste AJ, Matzuk MM (1998) The bone morphogenetic protein 15 gene is $X$-linked and expressed in oocytes. Mol Endocrinol 12: 1809-1817

Dufour CR, Wilson BJ, Huss JM, Kelly DP, Alaynick WA, Downes M, Evans RM, Blanchette M, Giguère V (2007) Genome-wide orchestration of cardiac functions by the orphan nuclear receptors ERRalpha and gamma. Cell Metab 5: 345-356

Dupont S, Kust A, Gansmuller A, Dierich A, Chambon P, Mark M (2000) Effect of single and compound knockouts of estrogen receptor $\alpha(E R \alpha)$ and $\beta(E R \beta)$ on mouse reproductive phenotypes. Development 127: 4277-4291

Durlinger AL, Kramer $P$, Karels B, de Jong FH, Uilenbroek JT, Grootegoed JA, Themmen AP (1999) Control of primordial follicle recruitment by anti-Müllerian hormone in the mouse ovary. Endocrinology 140: 5789-5796

Epifano O, Dean J (2002) Genetic control of early folliculogenesis in mice. Trends Endocrinol Metab 13: 169-173

Fitzpatrick SL, Funkhouser JM, Sindoni DM, Stevis PE, Deecher DC, Bapat AR, Merchenthaler I, Frail DE (1999) Expression of estrogen receptor- $\beta$ protein in rodent ovary. Endocrinology 140: 2581-2591

Forsberg J-G (1985) Treatment with different antiestrogens in the neonatal period and effects in the cervicovaginal epithelium and ovaries of adult mice: a comparison to estrogen-induced changes. Biol Reprod 32: 427-441

Giguère V, Yang N, Segui P, Evans RM (1988) Identification of a new class of steroid hormone receptors. Nature 331: 91-94

Gougeon A (1981) Frequent occurrence of multiovular follicles and multinuclear oocytes in the adult human ovary. Fertil Steril 35: 417-422

Graham CE, Bradley CF (1971) Polyovular follicles in squirrel monkeys after prolonged diethylstilbestrol treatment. J Reprod Fert 27: 181-185

Hanley NA, Ikeda Y, Luo X, Parker KL (2000) Steroidogenic factor 1 (SF-1) is essential for ovarian development and function. Mol Cell Endocrinol 163: 27-32

Hayashi S, Aihara M (1989) Neonatal estrogenization of the female rat: a useful model to analyse hypothalamic involvement of gonadotropin release. Zool Sci 6: 1059-1068

Hayashi S, Aihara M, Wakabayashi K (1991) Content and distribution pattern of luteinizing hormone-releasing hormone (LHRH) in the hypothalamus of neonatally estrogenized female rats. Neurosci Res 12: 366-378

Herbst AL, Bern HA (1981) Developmental Effects of Diethylstilbestrol (DES) in Pregnancy. Thieme Stratton, New York

Hiroi $\mathrm{H}$, Momoeda M, Inoue S, Tsuchiya F, Matsumi H, Tsutsumi O, Muramatsu M, Taketani $Y$ (1999) Stage-specific expression of estrogen receptor subtypes and estrogen responsive finger protein in preimplantational mouse embryos. Endocrinol J 46: 153158

HishikawaY, Damavandi E, Izumi S, Koji T (2003) Molecular histochemical analysis of estrogen receptor alpha and beta expression in the mouse ovary: in situ hybridization and South- 
ernwestern histochemistry. Med Electron Microsc 36: 67-73

Iguchi T (1985) Occurrence of polyovular follicles in ovaries of mice treated neonatally with diethylstilbestrol. Proc Jpn Acad B 61: 288-291

Iguchi T (1992) Cellular effects of early exposure to sex hormones and antihormones. Int Rev Cytol 139: 1-57

Iguchi T, Sato T (2000) Endocrine disruption and developmental abnormalities of female reproduction. Am Zool 40: 402-411

Iguchi T, Takasugi N (1986) Polyovular follicles in the ovary of immature mice exposed prenatally to diethylstilbestrol. Anat Embryol 175: 53-55

Iguchi T, Takasugi N, Bern HA, Mills KT (1986) Frequent occurrence of polyovular follicles in ovaries of mice exposed neonatally to diethylstilbestrol. Teratology 34: 29-35

Iguchi T, Ohta Y, Fukazawa Y, Takasugi N (1987) Strain differences in the induction of polyovular follicles by neonatal treatment with diethylstilbestrol in mice. Med Sci Res 15: 1407-1407

Iguchi T, Todoroki R, Takasugi N, Petrow V (1988) The effects of an aromatase inhibitor and a $5 \alpha$-reductase inhibitor upon the occurrence of polyovular follicles, persistent anovulation, and permanent vaginal stratification in mice treated neonatally with testosterone. Biol Reprod 39: 689-697

Iguchi T, Fukazawa Y, Uesugi Y, Takasugi N (1990) Polyovular follicles in mouse ovaries exposed neoneatally to diethylstilbestrol in vivo and in vitro. Biol Reprod 43: 478-484

Ikeda Y, Shen W-H, Ingraham HA, Parker KL (1994) Developmental expression of mouse steroidogenic factor 1 , an essential regulator of the steroid hydroxylases. Mol Endocrinol 8: 654-662

Ikeda Y, Nagai A, Ikeda M-A, Hayashi S (2001) Neonatal estrogen exposure inhibits steroidogenesis in the developing rat ovary. Dev Dynam 221: 443-453

Ikeda Y, Nagai A, Ikeda M-A, Hayashi S (2002) Increased expression of Müllerian-inhibiting substance correlates with inhibition of follicular growth in developing ovary of rats treated with E2 benzoate. Endocrinology 143: 304-312

Jakimiuk AJ, Weitsman SR, Yen H-W, Bogusiewick M, Magoffin DA (2002) Estrogen receptor $\alpha$ and $\beta$ expression in theca and granulosa cells from women with polycystic ovary syndrome. J Clin Endocrinol Metab 87: 5532-5538

Jefferson W, Newbold RR, Padilla-Banks E, Pepling M (2006) Neonatal genistein treatment alters ovarian differentiation in the mouse: inhibition of oocyte nest breakdown and increased oocyte survival. Biol Reprod 74: 161-168

Jefferson WN, Couse JF, Padilla-Banks E, Korach KS, Newbold RR (2002) Neonatal exposure to genistein induces estrogen receptor (ER) $\alpha$ expression and multioocyte follicle in the maturing mouse ovary: evidence for ER $\beta$-mediated and nonestrogenic actions. Biol Reprod 67: 1285-1296

Kent HA Jr (1960) Polyovular follicles and multinucleate ova in the ovaries of young mice. Anat Rec 137: 521-524

Kim H, Nakajima T, Hayashi S, Chambon P, Watanabe H, Iguchi T, Sato $T$ (2009) Effects of diethylstilbestrol on programmed oocyte death and induction of polyovular follicles in neonatal mouse ovaries. Biol Reprod, in press

Kipp JL, Kilen SM, Bristol-Gould S, Woodruff TK, Mayo KE (2007) Neonatal exposure to estrogens suppresses activin expression and signaling in the mouse ovary. Endocrinology 148: 19681976
Kuiper GGJM, Lemmen JG, Carlsson B, Corton JC, Safe SH, van der Saag PT, van der Burg B, Gustafsson JÅ (1988) Interaction of estrogenic chemicals and phytoestrogens with estrogen receptor $\beta$. Endocrinology 139: 4252-4263

Kuiper GGJM, Carlsosson B, Grandien K, Enmark E, Häggblad J, Nilsson S, Gustafsson J-Å (1997) Comparison of ligand binding specificity and transcript tissue distribution of estrogen receptor $\alpha$ and $\beta$. Endocrinology 138: 863-870

Lopez J, Ogren L, Verjan R, Talamantes F (1988) Effects of perinatal exposure to a synthetic estrogen and progestin on mammary tumorigenesis in mice. Terarology 38: 129-134

Luo J, Sladek R, Bader JA, Matthyssen A, Rossant J, Giguère V (1997) Placental abnormalities in mouse embryos lacking the orphan nuclear receptor ERR-beta. Nature 388: 778-782

Luo J, Sladek R, Carrier J, Bader JA, Richard D, Giguère V (2003) Reduced fat mass in mice lacking orphan nuclear receptor estrogen-related receptor alpha. Mol Cell Biol 23: 7947-7956

McGrath SA, Esquela AF, Lee SJ (1995) Oocyte-specific expression of growth/differentiation factor-9. Mol Endocrinol 9: 131-136

McMulle ML, Cho B-N, Yates CJ, Mayo KE (2001) Gonadal pathologies in transgenic mice expressing the rat inhibin alpha-subunit gene. Endocrinology 142: 5005-5014

Meunier H, Cajander SB, Roberts VJ, Rivier C, Sawchenko PE, Hsueh AJ, Vale W (1988) Rapid changes in the expression of inhibin $\alpha-, \beta A-$, and $\beta B$-subunits in ovarian cell types during the rat estrous cycle. Mol Endocrinol 2: 1352-1363

Nakamura T, Katsu Y, Watanabe H, Iguchi T (2008) Estrogen receptor subtypes selectively mediate female mouse reproductive abnormalities induced by neonatal exposure to estrogenic chemicals. Toxicology 253: 117-124

Pelletier G, El-Alfy M (2000) Immunocytochemical localization of estrogen receptors alpha and beta in the human reproductive organs. J Clin Endocrinol Metab 85: 4835-4840

Ryan KJ, Naftolin F, Reddy V, Flores F, Petro Z (1972) Estrogen formation in the brain. Am J Obst Gyn 114: 454-460

Sar M, Welsch F (1999) Differential expression of estrogen receptor- $\beta$ and estrogen receptor- $\alpha$ in the rat ovary. Endocrinology 140: 963-971

Scobie GA, Macpherson S, Millar MR, Groome NP, Romana PG, Saunders PT (2002) Human oestrogen receptors: differential expression of ER alpha and beta and the identification of ER beta variants. Steroids 67: 985-992

Takasugi N (1963) Vaginal cornification in persistent-estrous mice. Endocrinology 72: 607-619

Takasugi N (1976) Cytological basis for permanent vaginal changes in mice treated neonatally with steroid hormones. Int Rev Cytol 44: 193-224

Tremblay GB, Kunath T, Bergeron D, Lapointe L, Champigny C, Bader JA, Rossant J, Giguère V (2001) Diethylstilbestrol regulates trophoblast stem cell differentiation as a ligand of orphan nuclear receptor ERR beta. Genes Dev 15: 833-838

Weihua Z, Andersson S, Cheng G, Simpson ER, Warner M, Gustafsson J-Å (2003) Update on estrogen signaling. FEBS Lett 546: 17-24

Yan C, Wang P, DeMayo J, DeMayo FJ, Elvin JA, et al. (2001) Synergistic roles of bone morphogenetic protein 15 and growth differentiation factor 9 in ovarian function. Mol Endocrinol 15: 854-866

(Received May 27, 2009 / Accepted June 30, 2009) 